\title{
Silicon reduces brown spot severity and grain discoloration on several rice genotypes
}

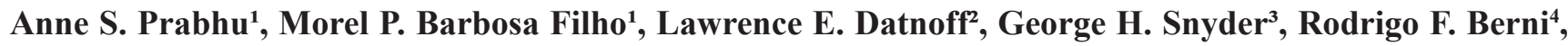 \\ Fabricio A. Rodrigues ${ }^{5}$ \& Leandro J. Dallagnol ${ }^{6}$
}

${ }^{1}$ Embrapa Arroz e Feijão, Cx. Postal 179, 75375-000, Santo Antônio de Goiás, GO, Brazil; ${ }^{2}$ Department of Plant Pathology and Crop Physiology, Louisiana State University Agricultural Center, 302 Life Sciences Bldg., Baton Rouge, LA, USA, 70803; ${ }^{3}$ University of Florida, Everglades Research and Education Center, P.O. Box 8003, Belle Glade, FL, USA, 33430; ${ }^{4}$ Embrapa Amazônia Ocidental, Cx. Postal 319, 69011-970, Manaus, AM, Brazil; ${ }^{5}$ Departamento de Fitopatologia, Universidade Federal de Viçosa, 36570-000, Viçosa, MG, Brazil; ${ }^{6}$ Departamento de Fitossanidade, Universidade Federal de Pelotas, 96010-900, Pelotas, RS, Brazil

Author for correspondence: Fabrício A. Rodrigues, e-mail address: fabricio@ufv.br

\begin{abstract}
This study aimed to investigate the effect of silicon ( $\mathrm{Si}$ ) on the reduction of brown spot severity (BSS), caused by Bipolaris oryzae, and grain discoloration in several rice genotypes. An experiment was conducted in a greenhouse where eight genotypes were evaluated for their response to Si rates and decrease on BSS. The relationship between Si rates and BSS was linear negative. Additionally, a field experiment was conducted including forty-eight genotypes which were grown in upland conditions and evaluated for their response to $\mathrm{Si}$ rates and reduction on grain discoloration. The relationship between Si rates and grain discoloration was quadratic negative. Weight of filled grains per panicle increased as the Si rates in the soil increased. Genotypic differences for Si concentration in husk were evident for both non-amended and Si-amended plots. While the Si concentration in husk increased to all genotypes, there was no relationship between grain discoloration and $\mathrm{Si}$ concentration in husk for plants from non-amended and Si-amended plots. The genotype CAN-7024 with the highest resistance to leaf brown spot also showed the lowest grain discoloration in comparison to the genotypes Casado and Caqui.
\end{abstract}

Key words: Bipolaris oryzae, Oryza sativa L., fungi associated to seeds, plant nutrition.

Grain discoloration caused by various fungal and bacterial pathogens is considered one of the major rice disease worldwide (Ou, 1985). In order of importance, the major pathogenic fungi causing grain discoloration in rice are Bipolaris oryzae (Breda de Haan) Shoemaker, Phoma sorghina (Sacc) Boerema, Dorenbosch \& Van Kesteren and Gerlachia oryzae (Hashioka \& Yokogi) Samuels and Hallett (Ou, 1985). Other fungi of sporadic occurrence include Alternaria padwickii (Ganguly) Ellis, Pyricularia grisea (Herbert) Barr, Curvularia spp., Nigrospora sp., and Fusarium spp., especially in upland rice ecosystems (Soave et al., 1997). Even though most of the bacterial diseases of rice cause grain discoloration, Pseudomonas glumae and Pantoea ananatis are the pathogens that attack primarily the glumes (Goto et al., 1988; Yan et al., 2010).

Grain discoloration starts at heading and continues until maturity, and is generally most severe under humid conditions (Ou, 1985). Glume blight, caused by P. sorghina, and brown spot, caused by $B$. oryzae, are the major fungal pathogens that reduce grain quality and weight in Brazil (Prabhu \& Lopes, 1980). Under epidemic years of glume blight, the reduction in grain weight can range from 29 to $45 \%$ and head milling yield from 0 to $14 \%$ (Prabhu
\& Bedendo, 1988). Bipolaris oryzae also causes grain discoloration in the United States (Marchetti \& Peterson, 1984). In Brazil, B. oryzae has been shown to cause from 12 to $30 \%$ reduction in grain weight and from 18 to $22 \%$ in filled grains per panicle, depending upon on the level of resistance of rice cultivars (Prabhu \& Lopes, 1980). Brown spot occurs on grains when plants are grown in nutrient-deficient soils, particularly those having low levels of calcium, iron, magnesium, manganese, potassium, and silicon (Webster \& Gunnel, 1992). Soils fertilized with both high and low nitrogen levels can also increase rice susceptibility to brown spot under upland conditions (Faria \& Prabhu, 1983). A number of commercial rice cultivars are known to exhibit different levels of resistance to grain discoloration (Malavolta et al., 2007).

Even though breeding for disease resistance is the most economical means to control grain discoloration, little success has been obtained because there are a number of different pathogens that may cause it. Grain discoloration is, in general, more severe when heading coincides with continuous rains and, as a consequence, fungicide efficiency is not very efficacious. Therefore, other cultural practices such as plant nutrition 
management is sought to reduce the disease impact on yield to acceptable levels.

Silicon ( $\mathrm{Si}$ ) fertilization has been reported to increase plant growth and development with a corresponding increase in grain yield (Savant et al., 1997). In upland rice, yields increased linearly with the application of increasing Si rates, and were positively correlated with $\mathrm{Si}$ and $\mathrm{Ca}$ levels in the soil (Barbosa Filho et al., 2001). In addition, Si fertilization has increased rice resistance to several important diseases, including brown spot (Datnoff et al., 2007). Datnoff et al. (1997) reported reductions in brown spot severity by 14 and $18 \%$, respectively, in treatments with residual $\mathrm{Si}$ in the soil and those that received new Si application. This result demonstrated that one year Si residual could significantly suppress brown spot development. In West Africa, the application of $18.7 \mathrm{~g}$ of $\mathrm{Si} / \mathrm{m}^{2}$, as sodium metasilicate, doubled Si uptake by plants and significantly reduced grain husk discoloration in upland rice grown on highly weathered Ultisols (Winslow, 1992). In studies conducted in the greenhouse with four different Si deficient savanna soils, Si increased total grain weight while decreasing grain discoloration regardless of the soil class (Korndörfer et al., 1999).

Since a paucity of information exists about the response of Brazilian rice genotypes in accumulating $\mathrm{Si}$ and suppressing brown spot severity and grain discoloration, the purpose of the present study was to evaluate the effect of Si on brown spot development and grain discoloration in several rice genotypes under both greenhouse and field conditions.

For the greenhouse experiment, seeds of the rice genotypes BG 367-4, Caiapo, Caqui, Casado, Can-7024, Guarani, Metica-1 and Rio Paranaíba were sown in plastic trays $(30 \times 10 \times 15 \mathrm{~cm}$ in size) containing $3 \mathrm{~kg}$ of perferric dark red latosol that was fertilized with $5 \mathrm{~g}$ of NPK (4-3016), $1 \mathrm{~g}$ of zinc sulfate and $2 \mathrm{~g}$ of ammonium sulfate two days before sowing. An additional $2 \mathrm{~g}$ of ammonium sulfate was applied 20 days after seedlings emergence. The experiment was arranged in a split-plot design with four replications. The main plots corresponded to the Si rates of $0,3,6,12$ and $24 \mathrm{~g}$ per tray, which corresponded to 0 , $486,972,1944$ and $3888 \mathrm{~kg} / \mathrm{ha}$ of $\mathrm{Si}$, respectively. The eight genotypes were the sub-plots. Ten seeds of each genotype were sown in eight $10 \mathrm{~cm}$ long rows per tray. Fifty-five day old plants were inoculated with a conidial suspension of $B$. oryzae $\left(6 \times 10^{5}\right.$ conidia $\left./ \mathrm{mL}\right)$. This suspension was prepared by using a monosporic isolate (CNPAF HO 82-1) of $B$. oryzae. The conidial suspension was sprayed onto rice leaves as a fine mist using a DeVilbiss $\mathrm{N}^{\circ} .15$ sprayer. The inoculated plants were kept in mist chamber for 48 hours $\left(25^{\circ} \mathrm{C}\right.$ and relative humidity of $\left.90 \pm 5 \%\right)$. After this period, plants were transferred to a greenhouse (temperature ranging from 25 to $29^{\circ} \mathrm{C}$ and relative humidity of $70 \pm 5 \%$ ). Brown spot severity (BSS) was evaluated on four leaves per plant at 10 days after inoculation by using a scale $1-9(1=$ $0 \%, 2=$ less than $1 \%, 3=1-3 \%, 4=4-10 \%, 5=11-15 \%$,
$6=15-25 \%, 7=26-50 \%, 8=51-75 \%$ and $9=76-100 \%)$ based on the percentage of diseased leaf area (IRRI, 1996). Data analysis was performed by using ANOVA and GLM procedures of SAS (SAS Institute, Cray, NC). Means were compared by Tukey's test and regression and correlation analysis were done to determine the relationship between BSS and Si rates.

The field experiment was carried out in an experimental area with history of brown spot epidemics at EMBRAPA-Rice and Beans Research Center, Santo Antônio de Goiás city, Brazil, under upland conditions. The soil class in the experimental area was Si-deficient typic perferric dark-red latosol with plant-available Si of $10.2 \mathrm{mg} \mathrm{dm}^{-3}$. The chemical characteristcs of the soil were: $\mathrm{pH}$ in $\mathrm{H}_{2} \mathrm{O}(1: 2.5)=5.4 ; \mathrm{Ca}^{2+}=22 \mathrm{mmol}_{\mathrm{c}} \mathrm{dm}^{-3} ; \mathrm{Mg}^{2+}=13$ $\mathrm{mmol}_{\mathrm{c}} \mathrm{dm}^{-3} ; \mathrm{P}=1.3 \mathrm{mg} \mathrm{dm}^{-3}$ and $\mathrm{K}=62.0 \mathrm{mg} \mathrm{dm}^{-3}$. The experimental design was a split-plot with three replications. Five $\mathrm{Si}$ rates $(0,188,376,564$ and $752 \mathrm{~kg} / \mathrm{ha})$, using wollastonite (Wansil-10, $\mathrm{CaSiO}_{3}$ ) as its source, were applied to the main plots. The wollastonite composition was: $\mathrm{SiO}_{2}$ $=50 \%(\mathrm{Si}=24.2 \%) ; \mathrm{CaO}=42.1 \%, \mathrm{Al}_{2} \mathrm{O}_{3}=1.82 \%, \mathrm{MgO}=$ $1.49 \%, \mathrm{Fe}_{2} \mathrm{O}_{3}=0.26 \%, \mathrm{Na}_{2} \mathrm{O}=0.22 \%$ and $\mathrm{MnO}=0.02 \%$. Dolomitic lime $(38.9 \% \mathrm{CaO}$ and $12.7 \% \mathrm{Mgo})$ was added to plots amended with $0,188,376$, and $564 \mathrm{~kg} \mathrm{Si} / \mathrm{ha}$ to equilibrate the amount of $\mathrm{Ca}$ present in these treatments with the treatment containing $752 \mathrm{~kg} \mathrm{Si} / \mathrm{ha}$ before sowing. Forty-eight rice genotypes were sowed to the sub-plots. Each sub-plot consisted of $2.0 \mathrm{~m}$ long single row. Seeds were drill sowed with $0.40 \mathrm{~m}$ row spacing at the rate of 40 $\mathrm{kg} / \mathrm{ha}$. NPK fertilizer (4-30-10) was applied at sowing at the rate of $400 \mathrm{~kg} / \mathrm{ha}$ in addition to $20 \mathrm{~kg} / \mathrm{ha}$ of zinc sulfate. An additional $40 \mathrm{~kg} / \mathrm{ha}$ of $\mathrm{N}$, in the form of ammonium sulfate, was applied as top dressing 63 days after sowing.

Evaluation of grain discoloration was based on a sample of five panicles collected from each genotype 10 days before grain harvest. A modified visual rating diagrammatic scale $(0,25,50,75$, and $100 \%$ of grain showing discoloration) developed by CIAT was used (CIAT, 1984) to assess grain discoloration (GD) on grains. Indeed, grain discoloration was evaluated by using a scale ranging from 0 to 4 where: $0=$ no discoloration on grains, $1=$ pin head spots on the grains, $2=25 \%$ of the area of grains with discoloration, and $4=$ more than $50 \%$ of the area of grains with discoloration. Data was used to calculate disease severity index (DSI) from samples obtained from 200 grains by using the formula: DSI = $\sum$ (class value $\times$ frequency / total number of grain $\times$ the highest class value).

The weight of filled grains (WFG) per panicle was based on a sample of 50 panicles per genotype. The grain weight was adjusted to $13 \%$ moisture. A bulked sample of $300 \mathrm{~g}$ of panicles collected from plants of non-amended and Si-amended $(752 \mathrm{~kg} / \mathrm{ha})$ plots from the three replications was used for $\mathrm{Si}$ analysis on grain husk tissue. Concentration of $\mathrm{Si}$ in grain husk was determined according to the method described by Snyder et al. (1986). 
Data analysis was performed by using ANOVA and GLM procedures of SAS (SAS Institute, Cary, NC). Data from DSI was transformed to $\arcsin \sqrt{\mathrm{x}}$. Means were grouped according to Scott \& Knott and regression and correlation analysis were performed with GD and WFG in function of the Si rates. Student's $t$ test was applied at 5 or $1 \%$ level of probability to compare means of Si concentration in grain husk $(n=48)$ from panicles collected from plants of nonamended and Si-amended plots.

For the greenhouse experiment, only the factors $\mathrm{Si}$ rates rice and genotypes were significant. The relationship between BSS and Si rates was linear negative ( $\mathrm{Y}=34.51$ - $0.0021 \mathrm{x}, \mathrm{R}^{2}=0.91$ ). Casado and Caqui were the most susceptible genotypes to brown spot while the CAN-7024 was the least susceptible (Figure 1).

Soil analysis after rice harvest showed no significant increase in $\mathrm{pH}$ in $\mathrm{H}_{2} \mathrm{O}(0=5.5,188 \mathrm{~kg} / \mathrm{ha}=5.5,376 \mathrm{~kg} / \mathrm{ha}$ $=5.6,564 \mathrm{~kg} / \mathrm{ha}=5.5$ and $752 \mathrm{~kg} / \mathrm{ha}=5.5)$ and $\mathrm{Ca}(0=22$ $\mathrm{mmol}_{\mathrm{c}} \mathrm{dm}^{-3}, 188 \mathrm{~kg} / \mathrm{ha}=22 \mathrm{mmol}_{\mathrm{c}} \mathrm{dm}^{-3}, 376 \mathrm{~kg} / \mathrm{ha}=24$ mmol $\mathrm{dm}^{-3}, 564 \mathrm{~kg} / \mathrm{ha}=24 \mathrm{mmol} \mathrm{dm}^{-3}$ and $752 \mathrm{~kg} / \mathrm{ha}=25$ $\mathrm{mmol}_{\mathrm{c}} \mathrm{dm}^{-3}$ ), indicating no increase in Ca levels in the soil as the $\mathrm{Si}$ rates increased from 0 to $752 \mathrm{~kg} / \mathrm{ha}$.

Only the factors Si rates and rice genotypes were significant for GD and WFG and the factor rice genotypes for DSI (Table 1). Rice genotypes were significantly different for GD and DSI (Table 2). The DSI ranged from 0.81 for cultivar CNA 7420 to 2.64 for Pai-kan-tao. The upland rice genotypes, constituting one distinct group ' $E$ ', exhibited the lowest GD and DSI values and differed from the other four groups. The tall upland cultivars of medium duration, widely used as susceptible checks in routine disease resistance evaluations, such as Casado, Nenezão, Tongil, Mimoso and short duration ones such as Caqui, IAC 21, Cajueiro liso, T.S. Phoma pertaining to group 'B' showed the highest GD and DSI values. This result indicated that high and uniform disease pressure occurred in the field conditions. The semi-dwarf indicas IR 8, IR 36, Metica-1,
TKM 6, BG 90-2, BG 367-4 as well as the American long grain cultivars Lebonet and Dawn pertaining to the same group were also highly susceptible to grain discoloration under upland conditions. The rest of the indica and japonica rice genotypes pertaining to groups $\mathrm{C}$ and $\mathrm{D}$ showed moderate resistance to grain discoloration. Values for WFG varied from 0.10 to $2.22 \mathrm{~g}$ for the different genotypes (Table 2). The upland rice genotypes CNA 7024, Caiapo and Rio Paranaíba pertaining to group A had the greatest values for WFG. The lower values for WFG were observed for some irrigated genotypes such as IR-8, Lebonet, Chokoto, Kanto 51, IR-50 and Zenith pertaining to group I.

There were significant differences among genotypes for Si concentration in grain husks for plants from nonamended and Si-amended plots (Table 2). Si concentration in grain husks significantly increased at the rate of $752 \mathrm{~kg} /$ ha and this averaged for all genotypes from 0.9 to $1.48 \mathrm{dag} /$ $\mathrm{kg}$. The increase in $\mathrm{Si}$ concentration ranged from 17.3 to $135 \%$ for Veneza Roxo and Lebonet, respectively, for the Si-amended plots compared to the non-amended plot. While the $\mathrm{Si}$ concentration varied for the different genotypes, there was no relationship between DSI and Si concentration in the husk for both Si-amended $(\mathrm{r}=-0.15, P=0.05)$ and non-amended treatments $(\mathrm{r}=0.029, P=0.05)$ (data not shown).

The relationship between GD and $\mathrm{Si}$ rates was quadratic negative $\left(\mathrm{Y}=63.62+0.0612 \mathrm{x}-0.0005 \mathrm{x}^{2}\right.$, $\left.\mathrm{R}^{2}=0.95\right)$. The correlation between GD and DSI was positive and significant $(\mathrm{r}=0.69, P=0.01, n=720)$. GD significantly reduced WFG $(\mathrm{r}=-0.39, P=0.01, n=720)$. The relationship between WFG and Si rates was positive and linear $\left(\mathrm{Y}=0.82+0.0004 \mathrm{x}, \mathrm{R}^{2}=0.97\right)$.

Silicon was effective in decreasing BSS and GD for a number of rice genotypes. The decrease in BSS by the Si rates indicates that higher leaf $\mathrm{Si}$ concentration increased genotype's resistance to brown spot as previously reported by Dallagnol et al. (2009). Similar results also were

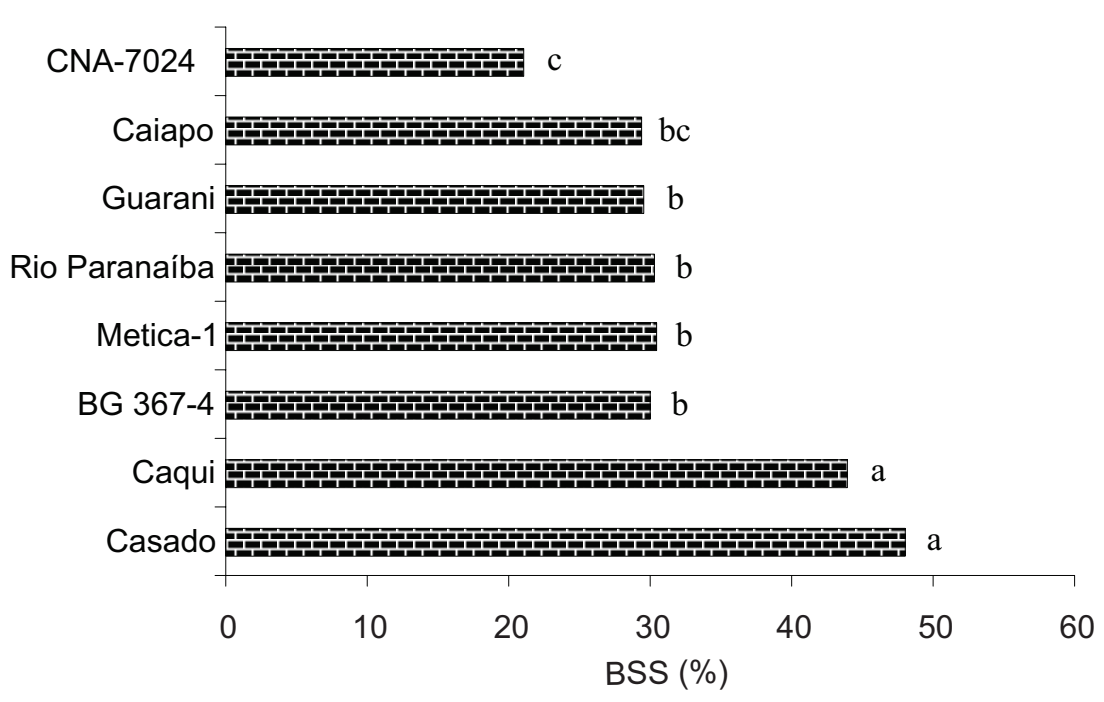

FIGURE 1 - Brown spot severity (BSS) on eight rice genotypes. Mean for each rice genotype was based on the average of five Si rates. Bars with the same letter do not differ significantly as determined by Tukey's test $(P=0.05)$. 
TABLE 1 - Analysis of variance of the effect of silicon rates and rice genotypes on grain discoloration (GD), disease severity index (DSI) and weight of filled grains (WFG) per panicle

\begin{tabular}{|c|c|c|c|c|c|c|c|}
\hline \multirow[t]{2}{*}{ Sources of variation } & \multirow[b]{2}{*}{ df } & \multicolumn{3}{|c|}{ Mean squares } & \multicolumn{3}{|c|}{$F$ values $^{\mathrm{a}}$} \\
\hline & & GD & DSI & WFG & GD & DSI & WFG \\
\hline Replications & 2 & 4976.6 & 1534.8 & 31.1 & $9.0^{* *}$ & $0.2^{\mathrm{ns}}$ & $3.0^{*}$ \\
\hline Silicon rates $(\mathrm{Si})$ & 4 & 7213.9 & 18543.7 & 202.7 & $12.9^{* *}$ & $2.2^{\mathrm{ns}}$ & $19.7^{* *}$ \\
\hline Error (a) & 8 & 550.4 & 8364.8 & 10.3 & - & - & - \\
\hline Genotypes (G) & 47 & 5481.6 & 21069.0 & 431.0 & $27.2^{* *}$ & $17.4^{* *}$ & $85.9^{* *}$ \\
\hline $\mathrm{Si} \times \mathrm{G}$ & 188 & 232.8 & 1358.4 & 4.5 & $1.2^{\mathrm{ns}}$ & $1.1^{\mathrm{ns}}$ & $0.9^{\mathrm{ns}}$ \\
\hline Error (b) & 470 & 201.5 & 1222.0 & 5.0 & - & - & - \\
\hline Total & 719 & & & & & & \\
\hline
\end{tabular}

$\mathrm{a}^{*}$ and ${ }^{* *}=$ significant at 0.05 and 0.01 levels of probability, respectively. ${ }^{\mathrm{ns}}=$ non significant. - $=$ not determined.

reported under field conditions in the US, where brown spot was significantly reduced by $\mathrm{Si}$, especially in moderately susceptible and susceptible rice cultivars (Datnoff et al., 1991). The effect of genotype resistance to leaf brown spot and grain discoloration was found to be similar for some genotypes under both greenhouse and field conditions. Rice genotypes with the highest leaf brown spot resistance also had the lowest DSI. The genotype CAN-7024 had the lowest BSS and DSI in comparison to the genotypes Casado and Caqui.

In the current study, the mean Si concentration in the husk of the rice genotypes increased for the Si treatment with significant differences among the genotypes. This result suggests that genotypes probably differ in their ability to accumulate Si especially in the husk. While Si concentration for the different genotypes varied, there was no detectable correlation between Si concentration on husk and DSI among them. However, the relationship between Si rates and GD was quadratic with the lowest GD values obtained for the highest $\mathrm{Si}$ rate. In studies conducted in Africa, a significant negative and linear correlation was obtained between husk discoloration and Si concentration (Winslow, 1992; Winslow et al., 1997). The results in the present study suggest that while $\mathrm{Si}$ reduces grain discoloration, the differential response of the rice genotypes to GD was not evident because the highest Si rate utilized was limited to $752 \mathrm{~kg} / \mathrm{ha}$. It is possible that these genotypes might show a better response in suppressing GD at higher $\mathrm{Si}$ rates. According to Snyder et al. (1986), the rice tissue must contain at least $3 \%$ of $\mathrm{Si}$ for better growth and great yield. Others have reported a Si tissue concentration of $5 \%$ or greater for optimizing yield (Savant et al., 1997; Dallagnol et al., 2009). Si concentrations between 3 and 5\% may be the minimum values needed for disease control in rice (Datnoff et al., 1997). The Si concentration in the rice husk of the genotypes appeared to be low and the differences in Si were specific to the type of plant tissue such as leaves or husks. In the present study, Si concentration in husk was much lower as compared to what has been reported for leaves, i. e. reaching up to $8 \mathrm{dag} / \mathrm{kg}$ (Dallagnol et al., 2009; Ma et al., 2002).
Besides Si concentration in husk, the genetically controlled genotypic resistance may also influence grain discoloration. This was found in the present study to which no detectable relationship was observed between Si concentration in husk and GD among the genotypes. Deren et al. (1994) demonstrated a significant and negative correlation between plant Si concentration and brown spot development among rice genotypes. Although there was a general trend across genotypes for decreasing brown spot development with increasing tissue Si concentration, there was one exception for the rice genotype Rico 1. Therefore, a genotype with a greater $\mathrm{Si}$ concentration may not necessarily be more disease resistant than a genoype that has a lower $\mathrm{Si}$ concentration when grown under the same $\mathrm{Si}$ fertility level (Kozaka, 1965). This result suggests that other genetic resistance factors are probably involved and similar findings were observed in the present study. Nevertheless, great genetic resistance and the ability to accumulate Si in the husk for the same genotype will be a viable measure to reduce GD. Reducing GD will also be reflected in a lower DSI as indicated by the positive correlation between these two variables. This resulted in yield increase as indicated by the negative correlation between GD and WFG. This finding is in agreement with studies conducted with upland rice genotypes in Colombia in relation to decrease grain discoloration caused mainly by B. oryzae (Winslow et al., 1997).

WFG varied significantly among the different genotypes. The upland rice genotypes showed the greatest values for WFG while the lowest values were observed for some irrigated genotypes which could be attributed to high grain sterility under upland conditions.

The mechanism(s) by which $\mathrm{Si}$ reduces grain discoloration has not been previously studied as with $M$. grisea or B. oryzae on leaves (Rodrigues et al., 2005; Brunings et al., 2009; Dallagnol et al., 2011). However, the overall decrease in grain discoloration of the rice genotypes with increasing Si rates possibly could be attributed to either the mechanical barrier formed after the polymerization of monosilicic acid below the cuticle or biochemical changes as previously reported for leaf brown spot (Savant et al., 
TABLE 2 - Grain discoloration (GD), disease severity index (DSI), weight of filled grains (WFG) per panicle and silicon ( $\mathrm{Si}$ ) concentration in husk for several rice genotypes grown in soil non-amended (0) or amended (752 kg/ha) with Si

\begin{tabular}{|c|c|c|c|c|c|}
\hline \multirow[b]{2}{*}{ Genotypes $^{a}$} & \multirow[b]{2}{*}{ GD $^{b}$} & \multirow[b]{2}{*}{ DSI $^{\mathbf{b}}$} & \multirow[b]{2}{*}{ WFG per panicle (g) } & \multicolumn{2}{|c|}{$\mathrm{Si}(\mathrm{dag} / \mathrm{kg})^{\mathrm{c}}$} \\
\hline & & & & $\mathbf{0}$ & $752 \mathrm{~kg} / \mathrm{ha}$ \\
\hline Pai-kan-tao $^{d}$ & $63.2 \mathrm{a}$ & $2.64 \mathrm{a}$ & $0.65 \mathrm{~g}$ & $0.99 \mathrm{c}$ & $1.42 \mathrm{c}$ \\
\hline Caqui $^{\mathrm{e}}$ & $59.2 \mathrm{~b}$ & $2.15 \mathrm{~b}$ & $1.43 \mathrm{c}$ & $1.04 \mathrm{~b}$ & $1.53 \mathrm{~b}$ \\
\hline Casado $^{\mathrm{e}}$ & $58.2 \mathrm{~b}$ & $2.04 \mathrm{~b}$ & $1.29 \mathrm{~d}$ & $0.96 \mathrm{c}$ & $1.48 \mathrm{c}$ \\
\hline $\operatorname{IR} 8^{\mathrm{d}}$ & $56.6 \mathrm{~b}$ & $2.01 \mathrm{~b}$ & $0.11 \mathrm{i}$ & $0.69 \mathrm{c}$ & $1.24 \mathrm{c}$ \\
\hline $\operatorname{IR} 36^{\mathrm{d}}$ & $55.2 \mathrm{~b}$ & $1.98 \mathrm{~b}$ & $0.56 \mathrm{~g}$ & $0.65 \mathrm{c}$ & $1.06 \mathrm{c}$ \\
\hline Metica $1^{\mathrm{d}}$ & $55.6 \mathrm{~b}$ & $1.98 \mathrm{~b}$ & $0.93 \mathrm{f}$ & $0.85 \mathrm{c}$ & $1.06 \mathrm{c}$ \\
\hline Nenezão $^{e}$ & $55.8 \mathrm{~b}$ & $1.98 \mathrm{~b}$ & $1.33 \mathrm{~d}$ & $0.90 \mathrm{c}$ & $1.42 \mathrm{c}$ \\
\hline Tongil $^{\mathrm{d}}$ & $55.7 \mathrm{~b}$ & $1.96 \mathrm{~b}$ & $1.13 \mathrm{e}$ & $0.86 \mathrm{c}$ & $1.60 \mathrm{~b}$ \\
\hline TKM $6^{\mathrm{d}}$ & $54.2 \mathrm{~b}$ & $1.95 \mathrm{~b}$ & $0.41 \mathrm{~h}$ & $0.74 \mathrm{c}$ & $1.14 \mathrm{c}$ \\
\hline $\operatorname{Mimoso}^{\mathrm{e}}$ & $51.2 \mathrm{~b}$ & $1.88 \mathrm{~b}$ & $1.13 \mathrm{e}$ & $1.03 \mathrm{~b}$ & $1.25 \mathrm{c}$ \\
\hline Ram Tulasi ${ }^{\mathrm{d}}$ & $51.2 \mathrm{~b}$ & $1.88 \mathrm{~b}$ & $1.01 \mathrm{e}$ & $1.14 \mathrm{~b}$ & $1.69 \mathrm{~b}$ \\
\hline BG 90-2 $2^{\mathrm{d}}$ & $51.2 \mathrm{~b}$ & $1.88 \mathrm{~b}$ & $0.68 \mathrm{~g}$ & $0.73 \mathrm{c}$ & $1.11 \mathrm{c}$ \\
\hline Lebonet $^{\mathrm{d}}$ & $51.4 \mathrm{~b}$ & $1.87 \mathrm{~b}$ & $0.17 \mathrm{i}$ & $0.77 \mathrm{c}$ & $1.81 \mathrm{~b}$ \\
\hline Dawn $^{\mathrm{d}}$ & $51.7 \mathrm{~b}$ & $1.86 \mathrm{~b}$ & $0.40 \mathrm{~h}$ & $0.62 \mathrm{c}$ & $1.24 \mathrm{c}$ \\
\hline BG $367-4^{\mathrm{d}}$ & $51.7 \mathrm{~b}$ & $1.86 \mathrm{~b}$ & $0.87 \mathrm{f}$ & $0.63 \mathrm{c}$ & $1.21 \mathrm{c}$ \\
\hline Chokoto $^{\mathrm{d}}$ & $51.8 \mathrm{~b}$ & $1.84 \mathrm{~b}$ & $0.23 \mathrm{i}$ & $0.94 \mathrm{c}$ & $1.22 \mathrm{c}$ \\
\hline Cajueiro Liso $^{\mathrm{e}}$ & $52.1 \mathrm{~b}$ & $1.84 \mathrm{~b}$ & $1.04 \mathrm{e}$ & $0.84 \mathrm{c}$ & $1.75 \mathrm{~b}$ \\
\hline T. S. Phoma ${ }^{\mathrm{e}}$ & $52.8 \mathrm{~b}$ & $1.84 \mathrm{~b}$ & $0.99 \mathrm{e}$ & $1.60 \mathrm{a}$ & $2.88 \mathrm{a}$ \\
\hline Kanto $51^{\mathrm{d}}$ & $49.7 \mathrm{c}$ & $1.79 \mathrm{c}$ & $0.19 \mathrm{i}$ & $0.73 \mathrm{c}$ & $1.18 \mathrm{c}$ \\
\hline Veneza Roxo ${ }^{\mathrm{e}}$ & $49.2 \mathrm{c}$ & $1.79 \mathrm{c}$ & $1.05 \mathrm{e}$ & $1.44 \mathrm{a}$ & $1.69 \mathrm{~b}$ \\
\hline IR $50^{\mathrm{d}}$ & $48.9 \mathrm{c}$ & $1.77 \mathrm{c}$ & $0.10 \mathrm{i}$ & $0.77 \mathrm{c}$ & $1.34 \mathrm{c}$ \\
\hline Branco Três Meses ${ }^{\mathrm{e}}$ & $47.2 \mathrm{c}$ & $1.76 \mathrm{c}$ & $1.21 \mathrm{~d}$ & $0.88 \mathrm{c}$ & $1.73 \mathrm{~b}$ \\
\hline Três Marias $^{\mathrm{d}}$ & $47.5 \mathrm{c}$ & $1.76 \mathrm{c}$ & $1.32 \mathrm{~d}$ & $1.10 \mathrm{~b}$ & $1.83 \mathrm{~b}$ \\
\hline Colômbia $1^{\mathrm{d}}$ & $46.9 \mathrm{c}$ & $1.75 \mathrm{c}$ & $0.75 \mathrm{~g}$ & $0.75 \mathrm{c}$ & $1.22 \mathrm{c}$ \\
\hline $\mathrm{IAC} 21^{\mathrm{e}}$ & $45.8 \mathrm{c}$ & $1.75 \mathrm{c}$ & $1.11 \mathrm{e}$ & $0.93 \mathrm{c}$ & $1.63 \mathrm{~b}$ \\
\hline Labelle $^{\mathrm{d}}$ & $45.2 \mathrm{c}$ & $1.71 \mathrm{c}$ & $0.44 \mathrm{~h}$ & $0.87 \mathrm{c}$ & $1.29 \mathrm{c}$ \\
\hline IRI $342^{\mathrm{d}}$ & $46.9 \mathrm{c}$ & $1.71 \mathrm{c}$ & $0.86 \mathrm{f}$ & $0.87 \mathrm{c}$ & $1.71 \mathrm{~b}$ \\
\hline IAC $165^{\mathrm{e}}$ & $47.3 \mathrm{c}$ & $1.68 \mathrm{c}$ & $0.37 \mathrm{~h}$ & $0.73 \mathrm{c}$ & $1.63 \mathrm{~b}$ \\
\hline IRAT $127^{\mathrm{e}}$ & $47.9 \mathrm{c}$ & $1.67 \mathrm{c}$ & $0.68 \mathrm{~g}$ & $0.88 \mathrm{c}$ & $1.38 \mathrm{c}$ \\
\hline $\operatorname{Shin} 2^{\mathrm{d}}$ & $46.8 \mathrm{c}$ & $1.59 \mathrm{c}$ & $1.01 \mathrm{e}$ & $0.76 \mathrm{c}$ & $1.23 \mathrm{c}$ \\
\hline Ceysovoni $^{\mathrm{d}}$ & $42.4 \mathrm{~d}$ & $1.52 \mathrm{~d}$ & $0.52 \mathrm{~h}$ & $0.90 \mathrm{c}$ & $1.30 \mathrm{c}$ \\
\hline $\operatorname{IR} 24^{\mathrm{d}}$ & $41.6 \mathrm{~d}$ & $1.50 \mathrm{~d}$ & $0.72 \mathrm{~g}$ & $0.94 \mathrm{c}$ & $1.35 \mathrm{c}$ \\
\hline $\operatorname{CNA} 7449^{\mathrm{e}}$ & $40.7 \mathrm{~d}$ & $1.48 \mathrm{~d}$ & $1.66 \mathrm{~b}$ & $0.85 \mathrm{c}$ & $1.58 \mathrm{~b}$ \\
\hline Zenith $^{\mathrm{d}}$ & $40.4 \mathrm{~d}$ & $1.45 \mathrm{~d}$ & $0.28 \mathrm{i}$ & $0.58 \mathrm{c}$ & $1.00 \mathrm{c}$ \\
\hline IRAT $140^{\mathrm{e}}$ & $39.9 \mathrm{~d}$ & $1.41 \mathrm{~d}$ & $0.95 \mathrm{f}$ & $0.74 \mathrm{c}$ & $1.37 \mathrm{c}$ \\
\hline IRI $344^{\mathrm{d}}$ & $39.2 \mathrm{~d}$ & $1.41 \mathrm{~d}$ & $1.03 \mathrm{e}$ & $0.88 \mathrm{c}$ & $1.63 \mathrm{~b}$ \\
\hline Arroz de Guerra ${ }^{e}$ & $38.7 \mathrm{~d}$ & $1.41 \mathrm{~d}$ & $1.27 \mathrm{~d}$ & $0.84 \mathrm{c}$ & $1.18 \mathrm{c}$ \\
\hline Myliang $30^{\mathrm{d}}$ & $38.4 \mathrm{~d}$ & $1.40 \mathrm{~d}$ & $0.44 \mathrm{~h}$ & $0.77 \mathrm{c}$ & $1.47 \mathrm{c}$ \\
\hline IRAT $104^{\mathrm{e}}$ & $37.2 \mathrm{~d}$ & $1.34 \mathrm{~d}$ & $1.82 \mathrm{~b}$ & $0.83 \mathrm{c}$ & $1.12 \mathrm{c}$ \\
\hline Guarani $^{\mathrm{e}}$ & $36.4 \mathrm{~d}$ & $1.23 \mathrm{~d}$ & $0.78 \mathrm{f}$ & $1.21 \mathrm{~b}$ & $2.14 \mathrm{~b}$ \\
\hline Pérola $^{e}$ & $35.6 \mathrm{~d}$ & $1.18 \mathrm{~d}$ & $1.62 \mathrm{~b}$ & $0.84 \mathrm{c}$ & $1.55 \mathrm{~b}$ \\
\hline Carajás $^{e}$ & $26.7 \mathrm{e}$ & $1.12 \mathrm{e}$ & $0.83 \mathrm{f}$ & $1.09 \mathrm{~b}$ & $1.69 \mathrm{~b}$ \\
\hline Rio Paranaíba ${ }^{\mathrm{e}}$ & $27.8 \mathrm{e}$ & $1.05 \mathrm{e}$ & $2.02 \mathrm{a}$ & $1.18 \mathrm{~b}$ & $1.81 \mathrm{~b}$ \\
\hline $\operatorname{IAC~} 47^{\mathrm{e}}$ & $27.9 \mathrm{e}$ & $1.01 \mathrm{e}$ & $1.48 \mathrm{c}$ & $1.17 \mathrm{~b}$ & $1.42 \mathrm{c}$ \\
\hline Araguaia $^{e}$ & $26.7 \mathrm{e}$ & $0.99 \mathrm{e}$ & $1.75 \mathrm{~b}$ & $1.04 \mathrm{~b}$ & $2.09 \mathrm{~b}$ \\
\hline Iguape Redondo $^{\mathrm{e}}$ & $25.4 \mathrm{e}$ & $0.92 \mathrm{e}$ & $1.23 \mathrm{~d}$ & $0.78 \mathrm{c}$ & $1.53 \mathrm{~b}$ \\
\hline Caiapó $^{\mathrm{e}}$ & $24.6 \mathrm{e}$ & $0.91 \mathrm{e}$ & $2.11 \mathrm{a}$ & $0.97 \mathrm{c}$ & $1.55 \mathrm{~b}$ \\
\hline $\mathrm{CNA}-7024^{\mathrm{e}}$ & $25.6 \mathrm{e}$ & $0.81 \mathrm{e}$ & $2.22 \mathrm{a}$ & $0.96 \mathrm{c}$ & $1.48 \mathrm{c}$ \\
\hline
\end{tabular}

${ }^{a}$ Means for rice genotypes followed by different letters within each column are significantly different based on the Scott $\&$ Knott test $(P=0.05)$. ${ }^{\mathrm{b}} \mathrm{GD}$ and $\mathrm{DSI}=$ values represent mean of the five Si rates.

${ }^{\mathrm{c}}$ Mean Si concentration in husk between non-amended $(0.90 \pm 0.28)$ and Si-amended $(752 \mathrm{~kg} / \mathrm{ha})(1.48 \pm 0.41)$ treatments differ by Student's $t$ test $(t=20.44, P=0.01)$.

${ }^{\mathrm{d}, \mathrm{e}}$ Irrigated and upland rice genotypes, respectively. 
1997; Dallagnol et al., 2011). The impact of Si to reduce grain discoloration may be of utmost importance to rice growers in Brazil since current commercial rice cultivars exhibiting satisfactory level of resistance to this disease are not available and fungicide management may be erratic at best.

\section{REFERENCES}

Barbosa Filho MP, Snyder GH, Fageria NK, Datnoff LE, Silva OF (2001) Silicato de cálcio como fonte de silício para o arroz de sequeiro. Revista Brasileira de Ciência do Solo 25:325-330.

Brunings AM, Datnoff LE, Ma JF, Mitani N, Nagamura Y, Rathinasabapathi B, Kirst M (2009) Differential gene expression of rice in response to silicon and rice blast fungus Magnaporthe oryzae. Annals of Applied Biology 155:161-170.

CIAT. Centro Internacional de Agricultura Tropical (1984) Escala ilustrada para evaluar germoplasma de arroz en el campo, según su grado de afección $(1,3,5,7$ ó 9) por manchado de grano. Arroz en las Américas 5:12.

Dallagnol LJ, Rodrigues FA, Mielli MVB, Ma JF, Datnoff LE (2009) Defective active silicon uptake affects some components of rice resistance to brown spot. Phytopathology 99:116-121.

Dallagnol LJ, Rodrigues FA, DaMatta FM, Mielli MVB, Pereira SC (2011) Deficiency in silicon uptake affects cytological, physiological, and biochemical events in the rice-Bipolaris oryzae interaction. Phytopathology 101:92-104.

Datnoff LE, Raid RN, Snyder GH, Jones DB (1991) Effect of calcium silicate on blast and brown spot intensities and yields of rice. Plant Disease 75:729-732.

Datnoff LE, Deren CW, Snyder GH (1997) Silicon fertilization for disease management of rice in Florida. Crop Protection 16:525531

Datnoff LE, Rodrigues FA, Seebold KW 2007. Silicon and plant disease. In: Datnoff LE, Elmer WH, Huber DM (Eds.) Mineral Nutrition and Plant Disease. St. Paul MN, USA. APS Press. pp. 233-246.

Deren CW, Datnoff LE, Snyder GH, Martin FG (1994) Silicon concentration, disease response, and yield components of rice genotypes grown on flooded organic Histosols. Crop Science 34:733-737.

Faria JC, Prabhu AS (1983) Relação entre fertilização nitrogenada e mancha parda do arroz em solos de cerrado. Pesquisa Agropecuária Brasileira 18:1377-1379.

Goto M, Zeigler RS, John VT (1988) Progress in seed health research on seed borne and contaminant bacteria, viruses and nematodes. Manila The Philippines. International Rice Research Institute.

IRRI (1996) Standard Evaluation System for Rice. $4^{\text {th }}$ Edition. Manila The Philippines. International Rice Research Institute.
Kozaka T (1965) Control of rice blast by cultivation practices in Japan. In: International Rice Research Institute Symposium on Rice Blast Disease, Proceedings... Baltimore MD, USA. John Hopkins Press. pp. 421-438.

Korndörfer GK, Datnoff LE, Corrêa GF (1999) Influence of silicon on grain discoloration and upland rice grown on four savanna soils of Brazil. Journal of Plant Nutrition 22:93-102.

Ma JF, Tamai K, Ichii M, Wu GF (2002) A rice mutant defective in Si uptake. Plant Physiology 130:2111-2117.

Malavolta VMA, Soligo EA, Dias DD, Azzini LE, Bastos CR (2007) Incidência de fungos e quantificação de danos em sementes de genótipos de arroz. Summa Phytopathologica 33:280-286.

Marchetti MA, Peterson HD (1984) The role of Bipolaris oryzae in floral abortion and kernel discoloration in rice. Plant Disease 68:288-291

Ou SH (1985) Rice Diseases. 2 $2^{\text {nd }}$ Edition. Kew England. Commonwealth Mycological Institute.

Prabhu AS, Bedendo IP (1988) Glume blight of rice in Brazil: etilogy, varietal reaction and loss estimates. Tropical Pest Management 34:85-88.

Prabhu AS, Lopes MA (1980) Infecção da folha e do grão de arroz por Helminthosporium oryzae e seus efeitos sobre os componentes de produção. Pesquisa Agropecuária Brasileira 15:183-189.

Rodrigues FA, Jurick WM, Datnoff LE, Jones JB, Rollins JA(2005) Silicon influences cytological and molecular events in compatible and incompatible rice-Magnaporthe grisea interactions. Physiological and Molecular Plant Pathology 66:144-159.

Savant NK, Snyder GH, Datnoff LE (1997) Silicon management and sustainable rice production. Advances in Agronomy 58:151199.

Snyder GH, Jones DB, Gascho GJ (1986) Silicon fertilization of rice on Everglades Histosols. Soil Science Society of America Journal 50:1259-1263.

Soave J, Prabhu AS, Ricci MT, Barros LG, Souza NRG, Curvo RCV, Ferreira RP, Sobral CAM (1997) Etiologia de manchas de sementes de cultivares de arroz de sequeiro no Centro-Oeste brasileiro. Summa Phytopathologica 23:122-127.

Webster RK, Gunnel PS (1992) Compendium of Rice Diseases. St. Paul MN, USA. APS Press.

Winslow MD (1992) Silicon disease resistance and yield of rice genotypes under upland cultural conditions. Crop Science 32:1208-1213.

Winslow MD, Okada K, Correa-Victoria F (1997) Silicon deficiency and the adaptation to tropical rice genotypes. Plant Soil 188:239-248.

Yan H, Yu SH, Xie GL, Fang W, Su T, Li B (2010) Grain discoloration of rice caused by Pantoea ananatis (synonym Erwinia uredovora) in China. Plant Disease 94:482. 